\title{
Is It Rude Language? Children Learning Pragmatics Through Visual Narratives
}

Noriko Ishihara

There has been an upsurge of interest in teaching second/foreign language (L2) pragmatics in recent years, but much of this effort has been targeted at adult learners. This article introduces small-scale informal instruction exploring the pragmatic development of 9-year-olds in Tokyo, facilitated through dialogic intervention on pragmatics using the visual presentation of narratives. Although the instruction took place in an English as a foreign language (EFL) context, the same dialogic approach is relevant to ESL in Canada and elsewhere, as picture books enrich narratives, visually mediating the context of language use in a manner comprehensible and captivating to young learners. The learners' pragmatic development was scaffolded dialogically through instructional materials doubling as teacher-based assessments, including formality judgment tasks, discourse completion tasks, and student-generated visual discourse completion tasks, assessed through predesigned rubrics and written reflections by the teacher. Video-recorded data showed that repeated visual assistance provided by the teacher and peers led to enhanced pragmatic awareness and metapragmatic judgments of the relative levels of formality and politeness of the target pragmatic formulas. However, with little L2 exposure, these learners were often unable to produce newly introduced expressions and failed to match the demands of the context with appropriate language choices during this isolated series of instructional events.

L'enseignement de la compétence pragmatique en langue secondelétrangère a connu un regain d'intérêt récemment, mais le gros de cet effort vise les apprenants adultes. Cet article présente un enseignement non structuré, à petite échelle, basé sur l'intervention dialogique consistant en la présentation visuelle de récits et visant le développement de la compétence pragmatique d'élèves de 9 ans à Tokyo. Même si l'enseignement a eu lieu dans un contexte d'anglais langue étrangère, la même approche dialogique est pertinente en anglais langue seconde au Canada et ailleurs puisque les livres d'images enrichissent le récit et jettent un pont visuel entre l'emploi de la langue et son contexte d'une manière compréhensible et captivante pour les jeunes. Le développement pragmatique des jeunes apprenants a été modulé de façon dialogique avec du matériel didactique qui servait également d'outil d'évaluation par l'enseignant. Ce matériel consistait, entre autres, en des tâches de jugement de formalité, des tâches d'achèvement du discours et des tâches d'achèvement du discours visuel proposées par les élèves et évaluées par des grilles prédéterminées et les réflexions écrites par l'enseignant. Les données provenant des enregistrements vidéo démontrent que l'appui visuel de la part de l'enseignant et des pairs a contribué au développement de la conscience pragmatique et des jugements méta-pragmatiques portant sur les niveaux relatifs de formalité et de 
politesse des formules pragmatiques visées. Toutefois, le peu d'exposition à la L2 a fait en sorte que les apprenants ne réussissaient pas souvent à produire des expressions nouvellement introduites et n'arrivaient pas à lier les exigences $d u$ contexte aux bons choix langagiers pendant ces séries indépendantes de leçons.

In recent years, an increasing level of attention has been paid to teaching pragmatics to second language (L2) learners. Practical resource books have been written, based on empirical evidence, and published nationally and internationally (e.g., Houck \& Tatsuki, 2011; Ronald, Rinnert, Fordyce, \& Knight, 2012; Tatsuki \& Houck, 2010), and a substantial literature in interlanguage pragmatics has emerged. While this is a welcome trend for teachers of adult learners, we should be alarmed that teachers of children are still largely left alone, with little guidance as to how they might introduce young children to pragmatics. Some may wonder whether children could ever understand the complexities involved in socially and culturally informed language choices. This concern may explain, at least partially, the absence of pragmatics-related components, especially at the beginner level, in many language curricula. However, should pragmatics be viewed simply as frills, a possible add-on to the L2 curriculum? Is it simply an area to be fine-tuned once the learners' proficiency has reached an intermediate or advanced level, even though pragmatic competence has been theoretically established as an indispensable component of communicative competence? And can L2 pragmatics be learned only in adulthood after the learners' cognitive ability is fully developed?

While only a small body of research exists on children's pragmatic development (Kasper \& Rose, 2002; Lee, 2010, 2012; Rose, 2000, 2005, 2009), there are signs that children do possess the ability to learn L2 pragmatics (see Ishihara \& Chiba, in press, for details). A few longitudinal observational studies of L2 children residing in target-language communities have documented several aspects of pragmatic development (e.g., a 7-year-old Japanese child learning to differentiate patterns of request realization in English according to her communicative goals [Achiba, 2003]; American siblings aged 7, 5, and 2 learning the use of interactional particles, direct or distal politeness levels, personal reference, and address forms in L2 Japanese more concretely and accurately than adult learners [Jones, 2007]). Because young learners are in the process of language socialization, it is unclear whether having rich interactional opportunities in the second language context ever requires systematic instructional intervention (Rose, 2005).

However, in foreign language (FL) contexts, the role of instruction in pragmatics may be more significant, as the classroom is typically the sole (or the major) source of L2 input and exposure. In FL immersion contexts, explicit instruction and exposure appears to have the potential to facilitate children's and adolescents' pragmatic development (see Kanagy, 1999; Kanagy \& Igarashi, 1997, for kindergartners' acquisition of formulaic expressions and 
routinized greeting sequences in Japanese immersion in the US; also relevant is Lyster, 1994, for positive effects of function-analytic instruction on eighth graders' sociolinguistic competence in French immersion in Toronto). However, because the context of immersion education is distinct from an English as a foreign language (EFL) context in terms of the quantity and quality of language input, output, and meaningful interaction (among other available resources), these findings are not readily comparable to those in EFL settings.

The small-scale informal instruction reported here attempts to explore the potential impact of pragmatics-focused L2 instruction on Japanese elementary students learning basic EFL. This paper reports the preliminary outcome of a dialogic approach to teaching pragmatics in which both visual narratives and dialogues were the locus of instruction. Narratives have been widely used for language learning and teaching as a means of constructing and reconstructing our personal and social knowledge. Narratives can serve as a mode of knowing and thinking (Carter, 1993) and can provide the rich sociocultural contexts that are crucial in learning pragmatics. In teaching children, narratives in picture books are reinforced by the eye-catching illustrations that visually provide even finer details of the context in a manner both captivating and comprehensible. The teacher can therefore steer dialogues with the children, directing their attention to pragmatically-relevant aspects of the story and the illustrations and possibly expanding the discussion beyond the immediate context.

Narratives can also be used as a catalyst for dialogic intervention. Through visual narratives, learners vividly see the consequences of verbal statements or non-verbal behaviors in the given context. By focusing on key features of the context and of language form, the teacher can navigate a pragmatics-focused discussion while scaffolding the learners in understanding sociocultural meaning in the text. In doing so, the teacher can build on the sociocultural knowledge the learners already possess in their first language (L)1. In line with Vygotskian sociocultural theory of learning, learners can co-construct pragmatic knowledge in interaction with peers and cognitively more advanced adults through language and cultural artifacts, in this case visual narratives and other learning aids (Lantolf \& Thorne, 2006; Vygotsky, 1978). In brief, narratives and dialogues have the potential to mediate the learners' cognitive development and to assist them in becoming gradually socialized into the practices of both the L1 and the L2 communities.

\section{Teaching Children Dialogically Through Visual Narratives}

The purpose of this informal instruction is not to generalize the insights gained to larger populations of learners but to identify and understand the process and nature of pragmatic learning in a bounded context, as preliminary findings could illuminate the direction of future instruction and research in wider contexts in this area. In a larger project, 13 Japanese learners of Eng- 
lish in four different contexts in Japan and Hong Kong received a similar (but not identical) intervention. Four teachers collaborated in designing pragmatics-focused instruction and assessment using five picture books written in English, and they implemented a selected subset in their individual contexts. Although the teachers shared the lesson plan prototypes, they used their own discretion in adapting the instructional goals, materials, and assessments to accommodate the demands of their own contexts. Thus, the instruction and learning outcomes are not readily comparable without carefully accounting for each instructional context. For this reason, this paper will focus on a subset of the data consisting of three learners in Japan (see Ishihara \& Chiba, in press, and Ishihara, Asaba, Burke, Chiba, \& Mboutsiadis, 2012, for the report of other Japanese and Hong Kong data).

\section{Participants}

The participants in this study were three 9-year-old boys attending a nationally supported elementary school in Tokyo. Although the three were close friends and classmates coming from families with similar socioeconomic status, their exposure to English varied, which reflects the reality of the variable access to English and English education in Japan. An initial learner background survey completed by their mothers showed that one of the learners, Masa (a pseudonym, as are the other learners' names) had almost no experience of English except for occasional basic English lessons in school. At the time this study was conducted, Masa was learning the English words for some vegetables and fruit orally through a game. He indicated no special interest in English and was reluctant to speak it. Another learner, Shota, had been taking English lessons in a private language school for 90 minutes each week for eight years (since age 1). He wanted to become able to speak English to be an astronaut in the future. He was extroverted and did much of the talking in this circle of friends. The other learner, Kengo, had also been learning English for one to two hours a week for eight years, mostly through videos, conversations at home, and annual family trips to the US. He viewed the learning of English as enjoyable and wished to speak English fluently. While Masa knew only individual letters and was illiterate in English, Shota and Kengo knew some basic spelling and had experienced or practiced some social interactions in English.

\section{The Instruction}

The participants received three pragmatics lessons spanning six weeks, for a total of 120 minutes $^{1}$ in an informal context using three English picture books, with a focus on the target pragmatic features listed in the table below. In consideration of the learners' age and L2 proficiency, the instruction was delivered in L1 Japanese as the metapragmatic discussion required a high level of cognitive thinking, such as comparing and contrasting, analyzing, 
and synthesizing newly-learned information. The use of the L1 also put learners on an equal linguistic footing, allowing them to formulate queries and hypotheses more thoroughly.

Table 1

Picture Books for Teaching Pragmatics and Target Pragmatic Features ${ }^{2}$

\begin{tabular}{|c|c|c|}
\hline$\underline{\text { Book title }}$ & Author(s) & Target pragmatic features \\
\hline \multirow[t]{3}{*}{ Martha speaks } & \multirow[t]{3}{*}{ Meddaugh } & Levels of directness and politeness \\
\hline & & $\begin{array}{l}\text { Sociopragmatically appropriate and less appropri- } \\
\text { ate behaviors }\end{array}$ \\
\hline & & Requests \\
\hline \multirow{2}{*}{$\begin{array}{l}\text { What do you say, } \\
\text { dear? }\end{array}$} & \multirow[t]{2}{*}{ Joslin } & Pragmatic formulas \\
\hline & & Levels of politeness and formality \\
\hline \multirow{4}{*}{$\begin{array}{l}\text { Forget their } \\
\text { manners }\end{array}$} & \multirow{4}{*}{$\begin{array}{l}\text { Berenstain \& } \\
\text { Berenstain }\end{array}$} & Pragmatic formulas \\
\hline & & Requests \\
\hline & & $\begin{array}{l}\text { Sociopragmatically appropriate and less appropri- } \\
\text { ate behaviors }\end{array}$ \\
\hline & & Urgency and politeness \\
\hline
\end{tabular}

In each session, a new book was read to the learners bilingually and explained in terms of meaning and cultural references. During this time, the learners engaged in discussions with each other and the teacher in Japanese over pragmatic language use. Later the target pragmatic features were revisited through a variety of visual aids, including a world map, handouts, and a formality scale consisting of a diagram of a continuum, with one end being formal and more polite and the other informal and less polite. ${ }^{3}$ Some of these visual aids doubled as teacher- or classroom-based assessment instruments (Hill \& McNamara, 2011; Ishihara, 2009), serving both evaluative and pedagogical purposes simultaneously (see Appendix for sample items):

1. Formality judgment tasks (FJTs), assessing the learners' understanding of the level of formality or politeness represented visually on the formality scale;

2. Discourse completion tasks (DCTs) ${ }^{4}$, assessing the learners' written pragmatic language production; and

3. Student-generated visual DCTs (SVDCTs), assessing the learners' language production and understanding of the context through their writing and drawing.

The teacher-based assessment instruments also included:

4. Pre-designed rubrics, evaluating what the learners were aware of and were able to do; and 
5. The teacher's written reflections, providing narrative observations about the dynamics among the children as well as the learning process.

Instruments 1-3 were printed on handouts, which were then collected as part of the teacher-based assessment. In addition, the entire instructional sequence was video-taped and transcribed for analysis to facilitate a close investigation of the nature of the classroom interaction. These interactional data were used to analyze how the learners' pragmatic development might have emerged through interaction.

Now let us turn to illustrations of the learning outcome observable in the interactional data, which were reinforced by the insights gained through the teacher-based assessments discussed above.

\section{Co-construction of (Meta)Pragmatic Awareness}

Because the learners had some prior exposure to basic English, the teacher tapped into this knowledge along with the learners' L1 pragmatic knowledge. In the second lesson, the narrative was structured so as to invite audience participation by introducing various situations and asking what the learners would say each time. In the first scene in What do you say, dear?, the learners saw a well-dressed gentleman giving away baby elephants on the street. The teacher asked what the learners would say if the gentleman introduced them to an elephant. The three learners said, respectively, "I'm Shota," "Hello," and "My name is Kengo." The next page of the book has How do you do? as an answer. As none of the learners was familiar with this expression, the teacher asked the learners about its level of formality: ${ }^{5}$

1 Teacher (T): $\quad$ Kore, donna kanji? How do you do? tte donna kanji?

This, what's this like? "How do you do?" What's it like?

2 Shota (S): Teineigo. Teinei, kashikomatta.

Polite language. Polite, formal.

$3 \mathrm{~T}$ :

Teineigo. Sou sou. Doushite wakaru?

4 S: Polite language. Right, right. How do you know? Ano, nanka, boushiwo kouiu fuuni (gestures) sagerutte kotowa...

Um, like, he is lowering his hat like this (gestures), which means...

5 T: Un. Uun.

Right. Yeah.

6 S:

Majishan tokamosa, boushi sageteru, ttekotowa yappari teineigoda.

Like magicians hold their hats low too. Which is, yes, it's polite language! 
Sou, soudayone. Kashikomatteruyone. Sou, dakara kocchino hou. (pointing to the left of the formality scale)

Right, isn't that right. Formal. So, around here. (pointing to the left of the formality scale)

As the first lesson centered on the topic of politeness and (in)formality, in Turn 2, Shota immediately identified How do you do? as polite and formal. When asked for a reason, he spontaneously relied on visual cues in the book to infer the level of formality of the situation and the politeness of the language (Turns 4,6 ). The teacher then used the previously introduced visual aid of the formality scale to underscore the idea of formality and politeness (Turn 7). Choral practice followed in the next four turns.

Later, in a handout, another expression, Nice to meet you, was also introduced as an informal counterpart in order to incorporate pragmatic variation and go beyond the prescriptive teaching of manners. This metapragmatic instruction also functioned to update potentially outdated pragmatic norms of behavior represented in this book (Joslin, 1958). On an FJT, the learners marked the right hand side of the formality scale printed on their handout, indicating that it was a friendlier, less formal expression (see Figure 1).

Eight days later, in the third lesson, during which this expression was reviewed through another handout, all three learners were able to identify with ease the relative levels of formality in these and six other formulaic expressions (i.e., You're welcome vs. No problem/no worries; Excuse me vs. I'm sorry; I beg your pardon? vs. Excuse me?), which appears to indicate their internalization of the metapragmatic judgments regarding these pragmatic formulas. The teacher noted her assessment of these points in the pre-designed rubrics after the second and third lessons (see \#1, 3, 5, 8 in Figure 2 in the subsequent section).

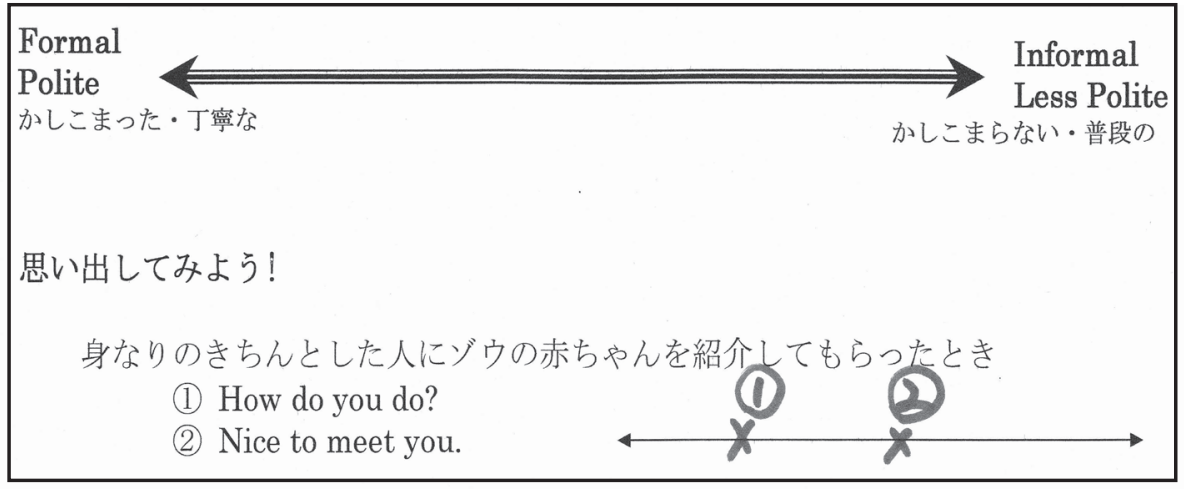

Figure 1: Sample Formality Judgment Task item 
Learners' reliance on the visual cues occurred frequently throughout the instruction as part of understanding pragmatic meaning (e.g., in identifying the relative directness or assertiveness of two expressions [Martha, please and Shut up!] by attending to the picture and the font size in the first lesson, and in identifying the level of formality of the phrase I beg your pardon? by noting the attire and social status of the characters in the second lesson). Attention to visual cues was paid sometimes spontaneously by the learners themselves, as in the first example above, while, at other times, the teacher directed the learners' attention to such clues in order to derive social meaning. In either case, the visual narratives assisted the learners in handling the learning task at the cognitive level, not exclusively at the language level. As they followed the plot in the picture books, which are often recursive in structure, the learners appeared to be dynamically and collaboratively coconstructing metapragmatic awareness and exercising it in understanding the narrative.

Toward the end of the final session, the teacher concluded the instruction by asking generally about the features of the books that the learners found interesting. Immediately after Masa answered this question (Turn 1 below), one of the scenes in the book caught Shota's attention (Turn 2):
1 M:
Katteni iroiro tanonjau.
She orders various things on her own.
2 S:
(pointing at one of the lines in the book) Nantte itterunda, korewa?
(pointing at one of the lines in the book) What's she saying here?
$3 \mathrm{~T}$ :
"Obaachan, osanpo ikanai," tte.
"Wanna go for a walk, Granny?"
4 S:
Shitsureina kotoba?
5 T:
Is it rude language?
Uun, korewa soudemo nai. Ano, furendoriina, kocchino futsuuno
(pointing on the formality scale), shitashimiyasui hyougenn dane.
No, not really. Um, a friendly expression, neutral, this side (pointing on the formality scale), a friendly expression.

Although Shota's question went off on a tangent, the teacher answered it by translating the line (Turn 3). Shota then asked whether it was rude language, demonstrating his enhanced pragmatic awareness (Turn 4). The teacher took this opportunity to indicate its level of formality on the formality scale (Turn 5). It is notable that this co-constructed incidental event was prompted by attention spontaneously paid by the learner to the pragmatic aspect of the language. This appears to demonstrate that the learner's en- 
hanced pragmatic awareness was applied autonomously to a novel situation within the instruction. While such an incidental display of spontaneous attention to pragmatics occurred only once, the learners' attention was constantly directed to the concepts of politeness and formality throughout the instruction.

\section{Limits to Pragmatic Development}

Despite the enhanced pragmatic awareness and metapragmatic judgments illustrated above, the learners' pragmatic development seemed to be less fruitful in terms of language production. As illustrated above, the learners sometimes encountered new pragmatic formulas during the instruction. Each time, these were practiced orally several times, analyzed in terms of the level of formality or politeness, revisited at the end of the lesson through DCTs and SVDCTs, and reviewed in the subsequent sessions. In the SVDCTs, the learners were able to show appropriate use of the pragmatic formulas with which they were already familiar (i.e., Hello, Nice to meet you) (see Ishihara \& Chiba, in press, for more about SVDCTs). Similarly, the six DCT items used in the second and third sessions revealed that the learners were able to readily produce the simple structure ... please in appropriate contexts but were unable to recall more complex and newly learned requests (e.g., Could I have...? Could you pass me...?). Perhaps they were resorting to a one-size-fits-all approach, using please as a politeness marker. This point surfaced in the teacher's assessment of the learning outcome for the pragmatic targets below (see Table 2).

Although the learners were able to reproduce new pragmatic formulas following the teacher's modeling during instruction, there was no indication that they were able to recall these at a later time. The instructional interaction revealed that some learners needed external scaffolding for a simple recall of some of these formulas. Because the learners had not internalized the relevant pragmalinguistic control, it is unlikely that they had self-regulated their use in appropriate contexts. Possible reasons include limited exposure to the L2, the learners' limited level of linguistic proficiency, and the nature of the instruction, which focused on general (meta)pragmatic awareness rather than on the acquisition of a small number of pragmatic expressions (see Ishihara \& Chiba, in press).

Another unplanned episode during the instruction appeared to reveal the limits of Masa's pragmatic competence. In the first two lessons, the function of the politeness marker and mitigator please, as well as the more polite expressions Could you/I..., please, came up recurrently in the books and was reviewed using two handouts. Each time, the language was analyzed in relation to the context. During the third lesson, Shota indicated that he wanted some water (Turn 1 below). Since the lesson took place in a private section of a restaurant, the teacher obtained the server's attention (Turn 2): 
$1 \mathrm{~S}:$

2 T:

3 M:

4 Server:

5 T:

6 Server:

7 S:

8 T: (suddenly) Omizuga hoshii.

(suddenly) I want some water.

A, omizu moraitai? (To a server) Sumimasen, omizu itadake masuka?

Oh, you want some water? (To a server) Excuse me, could we have some water?

(mumbles) jaa, water, please dana, imanowa.

(mumbles) So, this is, "Water, please."

(approaches) Hai.

(approaches) Yes?

A, omizu itadake masuka?

Um, could we have some water?

Hai.

Certainly.

Gomennasai, satsuei chuuni.

I'm sorry, we are filming.

Iiyo, iiyo, daijyoubu. Soredene, (to the server) arigatou gozaimasu.

Oh, no, not a problem. OK. (to the server) Thank you.

Here, the teacher spontaneously modeled an authentic polite request sequence in Japanese (Turns 2, 5, and 8). Masa, a less vocal learner with little prior experience of English, was listening, and he voluntarily applied it to L2 English (Turn 3). However, the teacher missed this at the time of instruction and returned to the previous dialogue.

When Shota's authentic L1 request was recast and modeled by the teacher, Masa was able to identify this real situation as requiring a polite expression in the L2. In fact, the teacher selected an expression in Japanese that is much higher in terms of politeness, indirectness, and formality than Water, please in English. While Masa was able to activate the concept of politeness in this context, his choice of the particular L2 expression was much less socially preferred, potentially bordering on rudeness. After viewing the video, the teacher reflected on this incident and wrote in her field notes: Masa got the pragmalinguistics [of the form ..., please] right but phrased the request in a less sociopragmatically appropriate manner. Real-life pragmatics is complex!

The limits to Masa's pragmatic competence may be due to his lack of pragmalinguistic control of the polite request required in this context. Although he was repeatedly exposed to more polite requests and practiced these orally during instruction, he was unlikely to have acquired their independent functioning. As a result, he seemed to resort to an approximation strategy using please. Alternatively, he may have been limited in his sociopragmatic judgment, thus failing to assess the demands of this authentic context and the face threats involved in the request, which required a more polite language choice 
than he had expected. More advanced language proficiency and more extensive pragmalinguistic practice as well as contextualized interactive output may assist learners in broadening the scope of the politeness strategies that could be activated in authentic contexts.

\section{Conclusion}

Because this exploratory study is based on a limited amount of instruction with a small number of learners, the findings cannot readily be generalized even to similar populations of young learners. Instead, the dialogic interaction occurring with the aid of teacher-based assessments appears to reveal both the benefits and limitations of the instruction for this particular group of

\section{Table 2}

Teacher's Assessment Through a Pre-designed Rubric

Assessment criteria
The learner is able to understand the different
levels of formality involved in at least two ex-
pressions including How do you do?
The learner is able to produce the expres-
sions (\#1) with appropriate gestures and/or
tone.
tone.

The learner is able to understand the different levels of formality involved in at least three expressions including You're welcome, No problem, No worries.

The learner is able to say/produce the expressions (\#2) with appropriate gestures or tone.

The learner is able to understand the relative levels of formality involved in at least two expressions including Excuse me and I'm sorry. The learner is able to produce at least two expressions including Excuse me and l'm sorry.

The learner is able to use an intensifier (very, so, or really) with an appropriate tone.

The learner is able to understand the relative levels of formality involved in at least two expressions including I beg your pardon? and Excuse me?

The learner is able to produce the expressions (\#7) with appropriate gestures or tone.
They could at least repeat. It's not clear whether they will be able to retain the two expressions taught.

Yes.

Yes, though retention is unknown.

Yes

Yes

Yes, they will probably remember these.

Yes, although the retention is unknown.

Yes

They didn't remember How do you do? at the start of this lesson. They may or may not have learned it in this lesson.

Yes

Yes, though retention is unknown.

Yes (especially Shota, who produced it spontaneously) Not assessed this time.

Yes

Yes, though the retention is unknown. 
children. In the interactive process of learning, co-constructed dialogue and visual narratives appeared to be critical ingredients, serving as the mediation for understanding social meaning. Paying attention to the visual cues provided by the narrative context and to politeness markers was not cognitively taxing for the learners. Rather, they seemed to have capitalized on this information as a helpful clue to social meaning. The repeated and explicit attention collaboratively paid to the formality of the context and the politeness in language appears to have led to the learners' enhanced pragmatic awareness of the interdependent relationship between context and language. The importance of repeated exposure seems to run parallel in Kanagy (1999) and Kanagy and Igarashi (1997), in which kindergartners were socialized into interactional routines and formulaic expressions through repeated exposure and participation. In the present study, the learners demonstrated their metapragmatic judgment by indicating relative levels of formality or politeness of target formulas through FJTs. An independent operation of this pragmatic awareness appeared to surface when one of the learners spontaneously inquired about the level of politeness upon encountering an unfamiliar expression.

However, their pragmatic awareness did not prove fruitful in language production. Perhaps due to their limited L2 proficiency and the nature of instruction focused on general (meta)pragmatic awareness, the learners were not able to completely self-regulate newly learned language. Moreover, given the lack of authentic opportunities to use the L2 and the limited amount of instruction, the learners may not have completely abandoned the one-sizefits-all approach, applying the "magic word" please to a situation they perceive as requiring politeness, a phenomenon also observed among Japanese university learners of English (Akutsu, 2012; Kasper \& Rose, 1999). Clearly, the depth of pragmatics cannot be taught thoroughly through this type of isolated instruction. Yet, continued and recurrent pragmatics instruction incorporated into regular language instruction has the potential to deliver promising results, especially in ESL contexts.

Although a strong case for the inclusion of pragmatics in the curriculum cannot be made on the basis of this informal instruction, it is hoped that it leaves the possibility open for more extensive explicit pragmatics instruction that may be able to plant pragmatic seeds in young learners of pragmatics. Given the current focus on intercultural understanding and language awareness in the elementary FL curriculum in Japan, enhanced (meta)pragmatic awareness in itself from the early stage of language learning can be valuable even if it is not yet closely linked to overall language proficiency. In ESL contexts, with greater exposure to the L2 and experience of real-life consequences of authentic language use, enhanced (meta)pragmatic awareness may assist learners in becoming better able to regulate their own intercultural learning. As story-telling is a commonly-adopted medium in elementary education, the type of pragmatics-focused dialogic intervention demonstrated in this 
paper could be seamlessly integrated into everyday instruction. Further research is needed to determine how the dynamics of a mainstream class may affect students' pragmatic learning over a more extended period of time and whether pragmatics can - or should be - taught explicitly and systematically to children from the initial stage of language instruction in various learning contexts.

\section{Notes}

${ }^{1}$ While the total time of the intervention was short and distributed sparsely, 120 minutes of instruction for third graders spread out over six weeks, as in this study, was not an anomaly in the local context. The required amount of instruction for fifth and sixth graders in Japan is 50 minutes per week and none is required for fourth graders and below as of 2011-2013.

2 See Ishihara et al. (2012) for two other books used in a larger study, and Asaba (2012) and Ishihara (2012) for published lesson plans.

${ }^{3}$ Notably, the constructs of formality and politeness cannot be equated. However, since the levels of politeness and formality of the target expressions introduced in the instruction in this study were often closely intertwined, these two concepts were presented to the learners in relation to each other.

${ }^{4}$ Although data elicited through DCTs may not accurately reflect natural speech and their validity has been questioned (e.g., Bardovi-Harlig \& Hartford, 2005; Ellis, 2008; Golato, 2003), DCTs can serve as a useful pedagogical tool and a viable instrument in eliciting learners' pragmatic production as well as their pragmatic knowledge (Rose, 2009).

${ }^{5}$ Samples of the interactional data in this paper were translated into English by the author and validated by another bilingual speaker using the back translation technique.

\section{Acknowledgements}

I would like to express my heartfelt thanks to the young participants and their guardians for their trust and support for this exploration. I am also grateful to Akiko Chiba, Megan Burke, Makiko Asaba, and Bill Mboutsiadis for their energetic and creative collaboration for the larger project. This research was funded by the Grant-in-Aid for Scientific Research (C) offered by the Japan Society for the Promotion of Science (\#24520657).

\section{The Author}

Noriko Ishihara, Ph.D. is Associate professor of EFL/TESOL at Hosei University, Japan. She also leads professional development courses in L2 pragmatics in Japan and at the Center for Advanced Research on Language Acquisition at the University of Minnesota. Her research interests include instructional pragmatics, curriculum development, identity, and teacher development.

\section{References}

Achiba, M. (2003). Learning to request in a second language: A study of child interlanguage pragmatics. Clevedon, UK: Multilingual Matters.

Akutsu, Y. (2012). Exploring meta-pragmatic awareness of Japanese learners of English: Focusing on speech act of request by lower-intermediate proficiency college students. Economic Journal of Takasaki City University of Economics, 54(4), 121-134.

Asaba, M. (2012). Owner's manual for sumimasen. In J. Ronald, C. Rinnert, K. Fordyce, \& T. Knight (Eds.), Pragtivities: Bringing pragmatics to second language classrooms (pp. 186-188). Tokyo: The Japan Association for Language Teaching Pragmatics Special Interest Group.

Bardovi-Harlig, K., \& Hartford, B. S. (Eds.). (2005). Interlanguage pragmatics: Exploring institutional talk. Mahwah, NJ: Lawrence Erlbaum. 
Berenstain, S., \& Berenstain, J. (1985). Forget their manners. New York, NY: Random House.

Carter, K. (1993). The place of story in the study of teaching and teacher education. Educational Researcher, 22(1), 5-12, 18.

Ellis, R. (2008). The study of second language acquisition (2nd ed.). Oxford, UK: Oxford University Press.

Golato, A. (2003). Studying compliment responses: A comparison of DCTs and recordings of naturally occurring talk. Applied Linguistics, 24(1), 90-121.

Hill, K., \& McNamara, T. (2011). Developing a comprehensive, empirically based research framework for classroom-based assessment. Language Testing, 29(3), 395-420.

Houck, N. R., \& Tatsuki, D. H. (Eds.). (2011). Pragmatics: Teaching natural conversation. Alexandria, VA: TESOL.

Ishihara, N. (2009). Teacher-based assessment for foreign language pragmatics. TESOL Quarterly, 43(3), 445-470.

Ishihara, N. (2012). Stories for children: My dog never says "please" and the talking dog. In J. Ronald, C. Rinnert, K. Fordyce, \& T. Knight (Eds.), Pragtivities: Bringing pragmatics to second language classrooms (pp. 189-196). Tokyo: The Japan Association for Language Teaching Pragmatics Special Interest Group.

Ishihara, N., Asaba, M., Burke, M., Chiba, A., \& Mboutsiadis, B. (2012, June). Visual narratives for L2 pragmatic learning: Sociocultural literacy development. Panel presented at the JALT Pan SIG Conference, Hiroshima University.

Ishihara, N., \& Chiba, A. (in press). Teacher-based or interactional?: Exploring means of assessment for children's pragmatic development. Iranian Journal of Language Testing.

Jones, K. (2007). The development of pragmatic competence in children learning Japanese as a second language. In D. R. Yoshimi \& H. Wang (Eds.), Selected papers from pragmatics in the CJK classroom: The state of the art (pp. 141-169). Honolulu, HI: University of Hawai'i at Manoa.

Joslin, S. (1958). What do you say, dear? New York, NY: Harper Collins Publishers.

Kanagy, R. (1999). Interactional routines as a mechanism for L2 acquisition and socialization in an immersion context. Journal of Pragmatics, 31(11), 1467-1492.

Kanagy, R., \& Igarashi, K. (1997). Acquisition of pragmatic competence in a Japanese immersion kindergarten. In L. F. Bouton (Ed.), Pragmatics and language learning: Monograph series (Vol. 8, pp. 243-265). Urbana-Champaign, IL: University of Illinois, Division of English as an International Language.

Kasper, G., \& Rose, K. R. (1999). Pragmatics and SLA. Annual Review of Applied Linguistics, 19, 81-104.

Kasper, G., \& Rose, K. R. (2002). Pragmatic development in a second language. Malden, MA: Blackwell.

Lantolf, J. P., \& Thorne, S. L. (2006). Sociocultural theory and the genesis of second language development. Oxford, UK: Oxford University Press.

Lee, C. (2010). An exploratory study of the interlanguage pragmatic comprehension of young learners of English. Pragmatics, 20(3), 343-373.

Lee, C. (2012). "Mum, sister hit me": Interlanguage complaint strategies of Cantonese learners of English from childhood to their teens. International Review of Pragmatics, 4(1), 80-109.

Lyster, R. (1994). The effects of functional-analytic teaching on aspects of French immersion students' sociolinguistic competence. Applied Linguistics, 15(3), 263-287.

Meddaugh, S. (1992). Martha speaks. New York, NY: Houghton Mifflin Company.

Ronald, J., Rinnert, C., Fordyce, K., \& Knight, T. (2012). Pragtivities: Bringing pragmatics to second language classrooms. Tokyo: The Japan Association for Language Teaching Pragmatics Special Interest Group..

Rose, K. R. (2000). An exploratory cross-sectional study of interlanguage pragmatic development. Studies in Second Language Acquisition, 22(1), 27-67.

Rose, K. R. (2005). On the effects of instruction in second language pragmatics. System, 33(3), 385-399. 
Rose, K. R. (2009). Interlanguage pragmatic development in Hong Kong, phase 2. Journal of Pragmatics, 41(11), 2345-2364.

Tatsuki, D. H., \& Houck, N. R. (Eds.). (2010). Pragmatics: Teaching speech acts. Alexandria, VA: TESOL.

Vygotsky, L. S. (1978). Mind in society: The development of higher psychological processes. Cambridge, MA: Harvard University Press.

\section{Appendix \\ Samples of Instructional and Assessment Materials}

\section{A. The formality scale}

\begin{tabular}{|lc|}
\hline 丁寧・ & 形式ばらない \\
かしこまった & 親しみやすい \\
Formal/ \\
Polite
\end{tabular}

\section{B. A formality judgment task (FJT)}

何と言うか思い出してみよう![Let's review! What do you say, when...] [The students were instructed to mark Xs on the formality scale below.]

1.オーケストラの音が大きくて、王妃のひみつが聞こえなかったと き [you couldn't hear the princess's secret because her orchestra is too loud:]

1 I beg your pardon?

2 Excuse me?

C. A discourse completion task (DCT)

こんな時は? [What do you say/do?]

1. ブロッコリーのお皿が遠くにあって届きません。[You want some broccoli but can't reach the dish on the table.]

\section{A student-generated visual DCT (SVDCT)}

チャレンジ! “What do you say?”で終わるシナリオを作ってみよ

う! [Let's make a scenario that ends with “What do you say?"]

こたえAnswer:

絵もかいてみてね。[Let's draw the scene below.] 